\title{
Evidence for mast cell activation during exercise-induced bronchoconstriction
}

\author{
S. O'Sullivan*, A. Roquet**, B. Dahlén**, F. Larsen**, A. Eklund**, M. Kumlin*, \\ P.M. O'Byrne+, S-E. Dahlén*
}

Evidence for mast cell activation during exercise-induced bronchoconstriction. S. O'Sullivan, A. Roquet, B. Dahlén, F. Larsen, A. Eklund, M. Kumlin, P.M. O'Byrne, S-E. Dahlén. CERS Journals 1998.

ABSTRACT: Controversy remains about the causative mediators in the bronchoconstrictive response to exercise in asthma. This study examined whether mast cell activation is a feature of exercise-induced bronchoconstriction by measuring urinary metabolites of mast cell mediators.

Twelve nonsmoking subjects with mild asthma and a history of exercise-induced bronchoconstriction exercised on a stationary bicycle ergometer for 5 min at $80 \%$ maximum work load. Pulmonary function was monitored and urine was collected before and 30 and $90 \mathrm{~min}$ after the provocation. The urinary concentrations of the mast cell markers $9 \alpha, 11 \beta$-prostaglandin $(\mathrm{PG}) \mathrm{F}_{2}$ and $N^{\tau}$-methylhistamine, as well as leukotriene $\mathrm{E}_{4}\left(\mathrm{LTE}_{4}\right)$ were determined by immunoassay.

Seven of the 12 subjects (responders) experienced bronchoconstriction ( $>15 \%$ fall in the forced expiratory volume in one second) following exercise, whereas the pulmonary function of the remaining five subjects (nonresponders) remained stable. The urinary excretion (mean $\pm \mathrm{SE})$ of $\mathbf{9} \alpha, 11 \beta-\mathrm{PGF}_{2}$ in the responders increased significantly compared with the nonresponders at $30(77.1 \pm 14.4$ versus $37.2 \pm 5.6 ; p<0.05)$ and 90 $\min (79.3 \pm 8.6$ versus $40.4 \pm 8.5, p<0.05)$ after exercise challenge. The urinary excretion of $N^{\tau}$-methylhistamine and $\mathbf{L T E}_{4}$ was not significantly different between the two groups at 30 or $90 \mathrm{~min}$ after exercise.

The findings represent the first documentation of increased urinary levels of $9 \alpha, 11 \beta$-prostaglandin $F_{2}$ in adults following exercise challenge and provides clear evidence for mast cell activation during exercise-induced bronchoconstriction in asthmatics.

Eur Respir J 1998; 12: 345-350.
*Experimental Asthma and Allergy Research, Institute of Environmental Medicine and **Division of Respiratory Medicine, Dept of Medicine at Karolinska Hospital, Karolinska Institutet, Stockholm, Sweden and +Dept of Medicine, McMaster University, Hamilton, Canada.

Correspondence: S. O'Sullivan, Experimental Asthma and Allergy Research, Institute of Environmental Medicine, Karolinska Institutet, S-171 77 Stockholm, Sweden. Fax: 468300619

Keywords: Exercise-induced bronchoconstriction, leukotrienes, mast cell, $N \tau$ methylhistamine, prostaglandin $D_{2}, 9 \alpha$, $11 \beta$-prostaglandin $\mathrm{F}_{2}$

Received: December 291997

Accepted after revision April 211998

Supported by grants from Karolinska Institutet and the following Swedish foundations: Heart Lung Foundation, Medical Research Council (project 14X-9071), the Foundation for Health Care Sciences and Allergy Research (Vårdal), the Association Against Asthma and Allergy and an operational grant from Zeneca Pharmaceuticals
Exercise-induced bronchoconstriction (EIB) is thought to occur in $70-80 \%$ of asthmatics, most commonly amongst those with moderate-to-severe airway hyperresponsiveness [1]. It is characterized by transient airflow obstruction resulting in a Š $15 \%$ decrease in forced expiratory volume in one second (FEV1) following 5-8 min of exercise. The fall in FEV1 reaches a maximum approximately 10 min after exercise and gradually normalizes over the next hour [2]. The precise pathophysiology of EIB remains unclear, although it is widely accepted that during exercise the upper airways are unable to adequately warm and humidify the increased volumes of inspired air. This results in airway cooling and increased airway fluid osmolality in the lower airways [3, 4]. One hypothesis suggests that hyperosmolar triggering of mast cells and possibly other inflammatory cells results in the release of bronchoconstricting mediators, e.g. cysteinyl-leukotrienes (cys-LTs), histamine and prostaglandin $\left(\mathrm{PG}^{2} \mathrm{D}_{2}[5]\right.$.

Previous indications for the participation of mast cell mediators in the pathogenesis of EIB are based on pharmacological data. For example, disodium cromoglycate (DSCG), a drug which stabilizes mast cell membranes, is effective in blunting exercise-induced asthma [6, 7]. Pretreatment with a number of $\mathrm{H}_{1}$ receptor antagonists has been shown to attenuate EIB [8-10]; however, the degree of protection afforded by this class of drugs has been modest. More recently, studies employing leukotriene receptor antagonists [11,12] and biosynthesis inhibitors [13] have implicated leukotrienes in the airway bronchoconstrictor response to exercise.

The direct approach of measuring mast cell mediator release in response to exercise challenge has yielded ambiguous results. Some studies have reported an elevation in plasma and whole blood histamine concentrations following EIB [14, 15], while other studies have failed to verify those findings $[16,17]$. Apart from the methodological problems encountered when sampling plasma histamine [18] and its short half-life in the circulation, approximately $1 \mathrm{~min}$ [19], it has been suggested that elevations in plasma histamine mainly reflect the basophilia which normally accompanies exercise [20]. Increases in the levels of tryptase and $\mathrm{PGD}_{2}$, both specific mast cell markers, have been detected in nasal lavage following nasal provocation with cold dry air [21], but not after exercise $[22,23]$.

The purpose of this study was to provide evidence to establish mast cell activation as a feature of EIB. To this end, a combination of mast cell markers, $9 \alpha, 11 \beta-\mathrm{PGF}_{2}$ 
and $N$-methylhistamine, was measured before and after exercise challenge in a group of asthmatics with a history of EIB. The major cyclooxygenase product of mast cells $\mathrm{PGD}_{2}$, is metabolized in the lung, via the action of the reduced nicotinamide adeine dinucleotide phosphate (NADPH)-dependent enzyme 11-ketoreductase to $9 \alpha, 11 \beta$ $\mathrm{PGF}_{2}$, and is excreted intact into the urine [24]. Since $\mathrm{PGD}_{2}$ production in humans is restricted almost exclusively to the mast cell [25], $\mathrm{PGD}_{2}$ and its metabolites may be employed as mast cell markers. In some reports macrophages [26] and platelets [27] have been ascribed the ability to synthesize $\mathrm{PGD}_{2}$; however, the levels reported are not of a comparable magnitude to those produced by mast cells.

Measurement of urinary metabolites of histamine overcomes the aforementioned problems with sampling plasma histamine. Thus, histamine is catabolized by $N$-methyltransferase to form $N^{\tau}$-methylhistamine, which is further broken down to form the principal urinary metabolite 1methyl-4-imidazoleacetic acid. Because of kinetic considerations this study measured $N^{\tau}$-methylhistamine, the earliest urinary metabolite of histamine to appear, which is a reliable marker of systemic histamine production [28]. The observation that histamine from skin mast cells is catabolized via an alternative pathway makes urinary $N \tau_{-}$ methylhistamine particularly useful in studies of pulmonary reactions.

With the exception of one study in children [29], it has not previously been possible to demonstrate increased levels of leukotriene $(\mathrm{LT}) \mathrm{E}_{4}$ in urine after exercise [30, 31]. Owing to the impressive pharmacological data implicating cys-LTs in EIB [11-13] and the abundant production of these compounds by the mast cell [32], urinary $\mathrm{LTE}_{4}$, which reflects changes in whole-body production of cysLTs [33], was also measured after exercise.

\section{Methods}

\section{Subjects}

Twelve nonsmoking subjects with mild asthma and a history of EIB participated in the study (table 1). The study was approved by the local Ethics Committee and informed consent was given by each subject. All subjects had stable asthma, controlled by inhaled $\beta_{2}$-agonists only. Ten subjects were atopic, as demonstrated by at least one positive skin-prick test to a set of 10 common allergens including house dust mite, birch and grass pollen and a selection of animal dander. The exercise challenges were performed out of the pollen season for sensitive individuals. Subjects were not permitted to use their $\beta_{2}$-agoinsts for at least $8 \mathrm{~h}$ before the exercise challenge and were instructed to avoid caffeine-containing drinks and strenuous exercise on the study day.

\section{Study design}

Each subject was studied at the same time in the morning. Immediately before exercise, baseline lung function was measured with an MDI Compact Vitalograph (Förbandsmaterial AB, Stockholm, Sweden) and the best of three FEV1 measurements was considered as the baseline value. Subjects exercised on a stationary bicycle ergometer (Seca Cardiotest 100, Hamburg, Germany), for 5 min at $80 \%$ maximum work load, which had been established at an earlier screening session. Subjects wore noseclips and breathed dry air $(0.005 \%$ humidity) at room temperature $\left(20^{\circ} \mathrm{C}\right)$ through a one-way mouthpiece from a $300 \mathrm{~L}$ Douglas bag, constantly fed with compressed air (AGA $\mathrm{AB}$, Lidingö, Sweden). Pulmonary function was monitored as FEV1 at $0,1,3,5,8$ and 10 min after exercise, and thereafter at $10 \mathrm{~min}$ intervals for up to $90 \mathrm{~min}$.

Subjects emptied their bladder $5 \mathrm{~min}$ before exercise and urine was collected again at 30 and 90 min after the end of the challenge. Urinary output was recorded at each urine collection and subjects were encouraged to drink a glass of water every hour. Creatinine was measured in all urine samples by a commercially available colorimetric assay (Sigma Chemical Company, St. Louis, MO, USA), using an alkaline picrate method, in order to correct for diuresis. Therefore, the urinary excretion of $9 \alpha, 11 \beta-\mathrm{PGF}_{2}$ and $\mathrm{LTE}_{4}$ was expressed as $\mathrm{ng} \cdot \mathrm{mmol}$ creatinine-1. Urine samples were stored, without the addition of any preservatives, at $-20^{\circ} \mathrm{C}$ until analysis.

Table 1. - Subject characteristics

\begin{tabular}{|c|c|c|c|c|c|c|c|}
\hline & $\begin{array}{l}\text { Subject } \\
\text { No. }\end{array}$ & $\begin{array}{l}\text { Age } \\
\text { yrs }\end{array}$ & Sex & $\begin{array}{l}\text { FEV1 } \\
\% \text { pred }\end{array}$ & $\begin{array}{l}\text { Workload } \\
\% \max \end{array}$ & $\begin{array}{c}\text { PD20 } \\
\text { histamine } \\
\mu \mathrm{g}\end{array}$ & Atopy \\
\hline 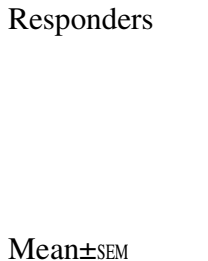 & $\begin{array}{l}1 \\
2 \\
3 \\
4 \\
5 \\
6 \\
7\end{array}$ & $\begin{array}{c}29 \\
22 \\
22 \\
28 \\
30 \\
24 \\
25 \\
257+12\end{array}$ & $\begin{array}{l}\mathrm{F} \\
\mathrm{M} \\
\mathrm{F} \\
\mathrm{M} \\
\mathrm{M} \\
\mathrm{M} \\
\mathrm{M}\end{array}$ & $\begin{array}{c}95 \\
83 \\
123 \\
84 \\
85 \\
97 \\
98 \\
95+53\end{array}$ & $\begin{array}{c}70 \\
80 \\
85 \\
80 \\
85 \\
75 \\
70 \\
779+24\end{array}$ & $\begin{array}{c}250 \\
900 \\
270 \\
150 \\
1350 \\
120 \\
115 \\
287(109-759)^{*}\end{array}$ & $\begin{array}{l}+ \\
- \\
- \\
+ \\
+ \\
+ \\
+\end{array}$ \\
\hline Nonresponders & 8 & $20.1-1$ & $\mathrm{~F}$ & 100 & (1.0. & - & + \\
\hline F & $\begin{array}{r}9 \\
10 \\
11 \\
12\end{array}$ & $\begin{array}{l}23 \\
36 \\
25 \\
19\end{array}$ & $\begin{array}{l}\mathrm{F} \\
\mathrm{M} \\
\mathrm{M} \\
\mathrm{F}\end{array}$ & $\begin{array}{r}105 \\
85 \\
97 \\
103\end{array}$ & $\begin{array}{l}85 \\
80 \\
85 \\
85\end{array}$ & $\begin{array}{r}>2000 \\
120 \\
250 \\
700\end{array}$ & $\begin{array}{l}+ \\
+ \\
+ \\
+\end{array}$ \\
\hline Mean \pm SEM & & $25.6 \pm 2.8$ & & $98 \pm 3.5$ & $81 \pm 2.9$ & $562(173-1820)^{*}$ & \\
\hline
\end{tabular}

F: female; M: male; FEV1: forced expiratory volume in one second; PD20: provocative dose of histamine causing a $20 \%$ fall in FEV1. *: Geometric mean and range. 


\section{Histamine provocation}

At least 1 week before exercise challenge, a bronchial challenge with histamine (histamine diphosphate was prepared by the hospital pharmacy) was performed as described previously [34]. In brief, histamine was inhaled from a jet nebulizer equipped with a dosimeter (Spira Electro 2; Respiratory Care Center, Hämeenlinna, Finland). Pulmonary function was monitored on a vitalograph as FEV1. The dose of histamine was increased by approximately half a log order of magnitude every 2 min until FEV1 had decreased by $20 \%$ or more.

\section{Enzyme immunoassay}

Enzyme immunoassay analyses of (EIA) $9 \alpha, 11 \beta-\mathrm{PGF}_{2}$ and $\mathrm{LTE}_{4}$ were performed in unextracted urine samples with polyclonal antisera and acetylcholinesterase-linked tracers (Cayman Chemical, Ann Arbor, MI, USA; Cascade Biochem, Reading, UK). The concentration of each sample was determined from a standard curve ranging from 7.8-1000 $\mathrm{pg} \cdot \mathrm{mL}^{-1}$. The precision of the EIA for $9 \alpha$, $11 \beta-\mathrm{PGF}_{2}[35]$ and $\mathrm{LTE}_{4}[36]$ is $9.7 \%$ and $17.6 \%$, respectively. Crossreactivity of the $9 \alpha, 11 \beta-\mathrm{PGF}_{2}$ antibody against an array of related compounds has been tested previously [34] and was: $\mathrm{PGD}_{2}, 1.7 \%$; $\mathrm{PGF}_{2 \alpha}, 1.7 \%$; 8-epi-PGF ${ }_{2 \alpha}$, $<0.01 \%$.

\section{Radioimmunoassay}

Measurements of urinary $N \tau$-methylhistamine were performed with a commercial double-antibody radioimmunoassay (Pharmacia AB, Uppsala, Sweden). The concentra-tion of $N^{\tau}$-methylhistamine in the sample was determined from a standard curve ranging from $0-10 \mu \mathrm{g} \cdot \mathrm{L}^{-1}$. Samples exceeding these concentrations were subsequently diluted to ensure that they fell within the standard curve. The de-tection limit for the assay was $0.1 \mu \mathrm{g} \cdot \mathrm{L}^{-1}$, as stated by the manufacturer, and the crossreactivity of the

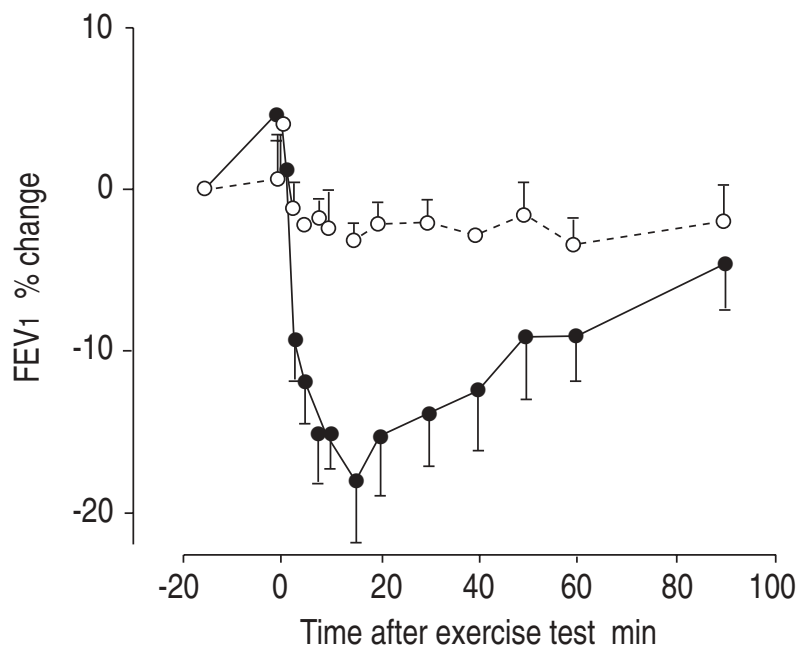

Fig. 1. - Mean ( \pm SEM) time course of forced expiratory volume in one second $\left(\mathrm{FEV}_{1}\right)$ values $(\%$ change from baseline) for the responders $(\bullet)$ and nonresponders $(O)$ following exercise challenge. Pulmonary function was measured before exercise, at 1,3, 5, 8 and 10 min after exercise and thereafter at $10 \mathrm{~min}$ intervals for up to $90 \mathrm{~min}$. antiserum with closely related compounds was as follows: histamine, $5.6 \%$; serotonin, $0.003 \%$; histidine, $0.0005 \%$. The precision of the radioimmunoassay for $N^{\tau}$-methylhistamine was $8.8 \%$. Concentrations of $N^{\tau}$-methylhistamine are express-ed as $\mu \mathrm{g} \cdot \mathrm{mmol}$ creatinine ${ }^{-1}$.

\section{Statistical analysis}

Calculations of geometric mean values of the provocative dose causing a $20 \%$ fall in FEV1 (PD20) were performed on log-transformed raw data. Exercise bronchoconstriction was determined as the maximal percentage change in FEV1 from baseline. All data are presented as mean \pm SE unless otherwise stated. Differences in the excretion of urinary mediators were compared by an unpaired Student's t-test and considered significant if the $\mathrm{p}$-value was $<0.05$. The statistical calculations were performed with the use of a validated statistical software package for personal computers (Sigma Suite ${ }^{\mathrm{TM}}$; Jandel Scientific, Sausalito, CA, USA).

\section{Results}

Seven of the 12 subjects experienced a decrease of S $15 \%$ in their FEV 1 values following 5 min of exercise at $80 \%$ of maximum workload (responders). The mean $\pm \mathrm{SE}$

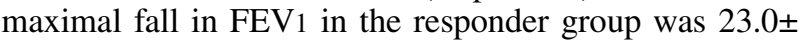
$8 \%$, with the peak bronchoconstriction occurring $15 \mathrm{~min}$ after completion of exercise (fig. 1). In contrast, the FEV 1 values for five of the subjects (nonresponders) remained stable after exercise, with a maximal drop of not $ð 4 \pm 0.9 \%$ from the pre-exercise baseline (fig. 1). The subject characteristics of the responder and nonresponder groups did not differ significantly from each other (table 1) although PD20 values for histamine were slightly higher amongst the responder group.

The mean urinary levels (ng.mmol creatinine-1) of $9 \alpha$, $11 \beta-\mathrm{PGF}_{2}, N$-methylhistamine and $\mathrm{LTE}_{4}$ before exercise did not differ between the responder and nonresponder

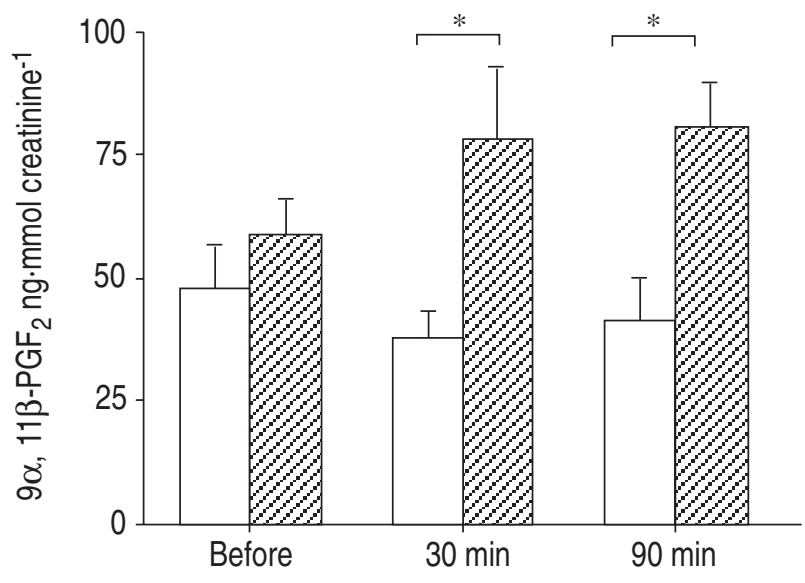

Fig. 2. - Mean (+SEM) urinary excretion of $9 \alpha, 11 \beta$-prostaglandin $(\mathrm{PG}) \mathrm{F}_{2}$ in the responder $(\square)$ and nonresponder $(\square)$ groups after 5 min of exercise. *: $\mathrm{p}<0.05$, significant increase in levels of $9 \alpha, 11 \beta$ $\mathrm{PGF}_{2}$ in the responder group at 30 and 90 min compared with the nonresponders at the same time points. The concentration of $9 \alpha, 11 \beta-\mathrm{PGF}_{2}$ in the responder group at $90 \mathrm{~min}$ was also significantly increased $(\mathrm{p}<0.05)$ above baseline levels. 


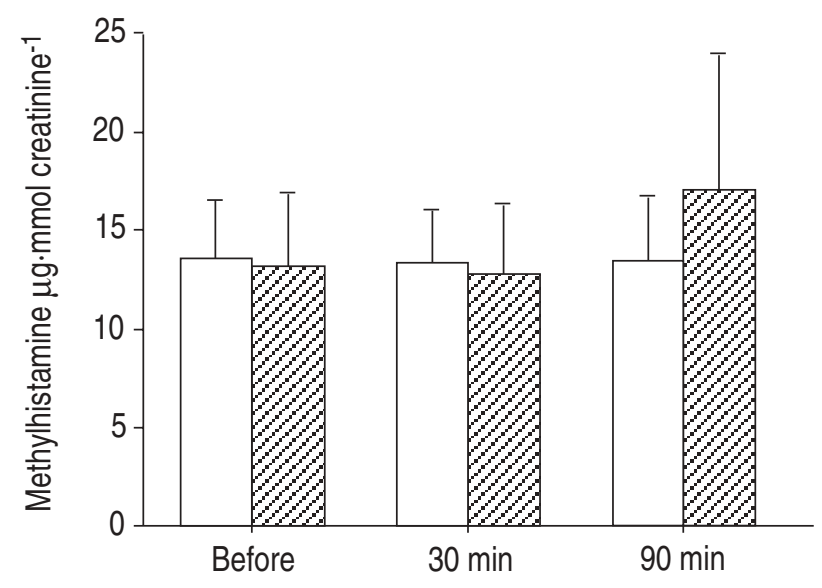

Fig. 3. - Mean (+SEM) urinary excretion of $N^{\tau}$-methylhistamine in the responder ( $Q$ ) and nonresponder ( $\square$ ) groups before and 30 and 90 min after exercise.

groups, as assessed by an unpaired t-test. Mean urinary excretion of $9 \alpha, 11 \beta-\mathrm{PGF}_{2}$ in the responder group increased significantly compared with the nonresponders at 30 $\min (37.2 \pm 5.6$ versus $77.1 \pm 14.4 ; \mathrm{p}<0.05)$ and $90 \mathrm{~min}$ (40.4 \pm 8.5 versus $79.3 \pm 8.6 ; \mathrm{p}<0.05)$ after completion of the exercise challenge (fig. 2). The concentration of $9 \alpha$, $11 \beta-\mathrm{PGF}_{2}$ in the responder group at $90 \mathrm{~min}$ was also significantly increased above the prechallenge level in this particular group $(58.3 \pm 7.0$ versus $79.3 \pm 8.6 ; \mathrm{p}<0.05)$. There was an increase in levels of $N^{\tau}$-methylhistamine after 90 min but it failed to reach statistical significance (fig. 3). In the case of urinary $\mathrm{LTE}_{4}$, the excretion was not significantly different between the two groups at 30 or $90 \mathrm{~min}$ after exercise (fig. 4). There was, however, a propensity for a decrease from baseline values of urinary $\mathrm{LTE}_{4}$ in the nonresponder group after exercise.

\section{Discussion}

The role of the mast cell and its spasmogenic mediators in exercise-induced bronchoconstriction has attracted considerable attention; however, the literature to date concerning the detection of mast cell-derived mediators in EIB has been equivocal. The results of the present investigation provide novel direct evidence that the mast cell is activated during EIB. In association with EIB in a group of asthmatics there was a significant postexercise increase in the urinary level of the $\mathrm{PGD}_{2}$ metabolite, $9 \alpha, 11 \beta-\mathrm{PGF}_{2}$. In contrast, the level of $9 \alpha, 11 \beta-\mathrm{PGF}_{2}$ was unaltered in the group that did not experience EIB. These findings represent the first documentation of increased urinary levels of the $\mathrm{PGD}_{2}$ metabolite in adults following EIB. They are in excellent agreement with the results of NAGAKURA et al. [37], who recently found an increase of similar magnitude in urinary $9 \alpha, 11 \beta-\mathrm{PGF}_{2}$ in children following exercise, when samples were analysed by gas chromatography mass spectrometry (GC/MS) [37]. Release of a mast cell mar-ker during EIB corroborates evidence of an increased percentage of degranulating mast cells in bronchial biopsies after EIB [38].

Previously, several groups have utilized histamine as a marker for mast cell activation in EIB, without producing conclusive results [14-17]. This confusion is probably due

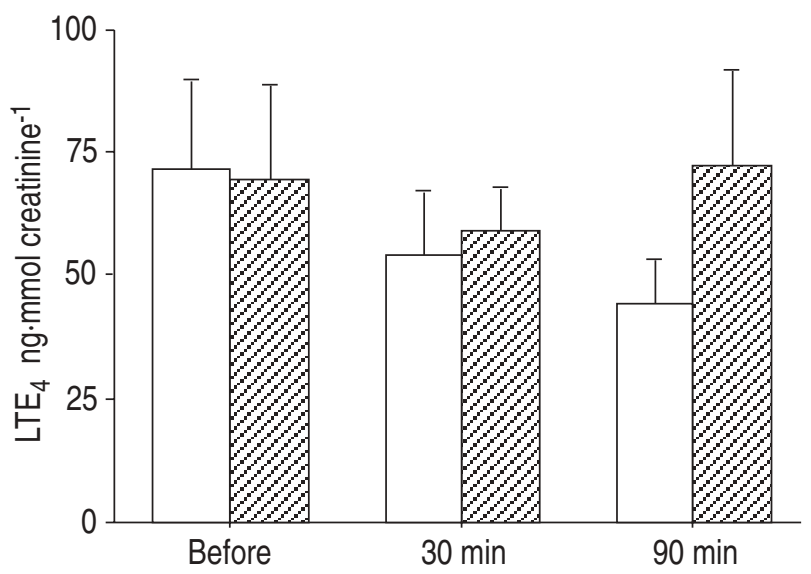

Fig. 4. - Mean (+SEM) urinary excretion of leukotriene (LT)E $\mathrm{E}_{4}$ in the responder ( $\square$ ) and nonresponder ( $\square$ ) groups before and 30 and 90 min after exercise.

to the technical difficulties with measuring small changes in circulating concentrations of histamine following exercise. Since the basophil is another potential source of histamine, it has been suggested that the increases in plasma or whole-blood histamine can be attributed to the basophilia which ensues exercise [20,39]. However, NAGAKURA et al. [40] demonstrated a rise in histamine that was restricted to those who had experienced EIB, despite the fact that both EIB-positive and EIB-negative asthmatics had similar postexercise basophilia. Measurements of increased mast cell-associated neutrophil chemotactic factor (NCF) following exercise $[15,41]$ lend further support to the hypothesis that mast cells are activated during EIB.

No increase in the urinary excretion of $N$-methylhistamine could be demonstrated following EIB, although a trend towards increased levels of this metabolite was observed 90 min after exercise. The present findings confirm previous negative data from studies in which $N^{\tau}$-methylhistamine [42] and 1-methyl-4-imidazoleacetic acid [43], the major urinary metabolite of histamine, were determined following EIB. In a recent study conducted in our laboratory where atopic asthmatics were challenged with allergen, it was observed that in all cases where $N^{\tau}$-methylhistamine levels were elevated above prechallenge level, the concomitant relative increases in $9 \alpha, 11 \beta-\mathrm{PGF}_{2}$ were greater [44]. The $30 \%$ increase in levels of $9 \alpha, 11 \beta-\mathrm{PGF}_{2}$ following exercise is very much lower than the approximate 200-300\% increase seen after allergen challenge [35]. It therefore appears that $9 \alpha, 11 \beta-\mathrm{PGF}_{2}$ is more sensitive than $N^{\tau}$-methylhistamine for monitoring mild and transient episodes of mast cell activation. In addition, in contrast to the rapid turnover of plasma histamine [19], $N^{\tau}$-methylhistamine has a comparatively long half-life. Following intrabronchial administration of ${ }^{14} \mathrm{C}$-histamine to a group of asthmatics, excretion of labelled $N^{\tau}$-methylhistamine was complete within $3 \mathrm{~h}$, with the majority of the metabolite being detected in the urine during the first hour after administration, while excretion of 1-methyl-4imidazoleacetic acid peaked after $6 \mathrm{~h}$ [28]. Since urine was collected between 30 and 90 min after the challenge the peak excretion of $N^{\tau}$-methylhistamine may have been missed.

Exercise-induced bronchoconstriction was not associated with an increased excretion of urinary $\mathrm{LTE}_{4}$, thereby 
confirming previous studies which have failed to detect increased $\mathrm{LTE}_{4}$ concentrations in urine $[30,31]$ or bronchoalveolar lavage fluid [23] following exercise. Metabolism of leukotrienes in the lung is very rapid, with inhaled leukotrienes recovered in the urine within $1 \mathrm{~h}$ of inhalation [45]. It is therefore reasonable to expect that with urine collections at 30 and 90 min after exercise, increased generation of leukotrienes could have been detected. It may be that local increases in leukotriene production in the lung are not of a sufficient magnitude to alter urinary concentrations of $\mathrm{LTE}_{4}$. It is noteworthy that during the reivew of this manuscript ReIss et al. [46] have published a report in which they demonstrated a small but significant twofold increase in urinary $\mathrm{LTE}_{4}$ in a group of 13 asthmatics after exercise challenge. Previous studies, including our own, have included 6-9 subjects and it may be that the expanded number of subjects was a contributory factor in obtaining an increase in urinary LTE $_{4}$ after an exercise challenge. As evidenced by a strong body of pharmacological data from studies with the cys-LT receptor antagonists $[11,13]$, there is no doubt that the cys-LTs are major mediators of EIB.

Exercise is a much less vigorous challenge than allergen provocation, where mediators can be elevated in the blood and urine for several hours. The difficulty encountered with demonstration of various mediators following exercise-induced bronchoconstriction presumably relates to the inferior strength and short duration of the stimulus. Therefore, the findings of increased urinary levels of $9 \alpha$, $11 \beta$-prostaglandin $\mathrm{F}_{2}$ provide strong new evidence for mast cell activation during exercise-induced bronchoconstriction. The findings also support the usefulness and sensitivity of $9 \alpha, 11 \beta$-prostaglandin $F_{2}$ as a mast cell marker.

Acknowledgements: The authors wish to thank M. Dahl, G. de Forest, L. Larsson and K. Ström for excellent and dedicated assistance.

\section{References}

1. Anderson SD, Silverman M, Godfrey S, Konig P. Exercise-induced asthma; a review. Br J Dis Chest 1975; 69: $1-39$.

2. Freed AN. Models and mechanisms of exercise-induced asthma. Eur Respir J 1995; 8: 1770-1785.

3. Deal EC Jr, McFadden EE Jr, Ingram RH Jr, Strauss RH $\mathrm{Jr}$, Jaegger JJ. Role of respiratory heat exchange in production of exercise-induced asthma. J Appl Physiol 1979; 46: 467-475.

4. Togias AG, Proud D, Lichtenstein LM, et al. The osmolality of nasal secretions increases in the inflammatory response to inhalation of cold, dry air. Am Rev Respir Dis 1988; 137: 625-629.

5. Anderson AD, Daviskas E, Smith CM. Exercise-induced asthma: a difference in opinion regarding the stimulus. Allergy Proc 1989; 10: 215-216.

6. Davies SE. The effect of disodium cromoglycate on exercise-induced asthma. BMJ 1986; 3: 1328-1329.

7. Silverman M, Andrea T. Time course of effect of disodium cromoglycate on exercise-induced asthma. Arch Dis Child 1972; 47: 419-422.

8. Finnerty JP, Holgate ST. Evidence for the roles of histamine and prostaglandins as mediators in exercise-induced asthma: the inhibitory effect of terfenadine and flurbiprofen alone and in combination. Eur Respir J 1990; 3: 540547.
9. Hartley JPR, Norgrady SG. Effect of an inhaled antihistamine on exercise-induced asthma. Thorax 1980; 35: 593594.

10. Magnussen H, Reuss G, Jorres A, Aurich R. Effect of azelastine on exercise-induced asthma. Chest 1988; 93: 937-940.

11. Finnerty JP, Wood-Baker R, Thomson H, Holgate ST. Role of leukotrienes in exercise-induced asthma. Inhibitory effect of ICI 204219, a potent leukotriene $\mathrm{D}_{4}$ receptor antagonist. Am Rev Respir Dis 1992; 145: 746-749.

12. Manning PJ, Watson RM, Margolskee DJ, Williams VC, Schwartz JI, O'Byrne PM. Inhibition of exercise-induced bronchoconstriction by MK-571, a potent leukotriene $\mathrm{D}_{4}$ receptor antagonist. N Engl J Med 1990; 323: 17361739.

13. Meltzer SS, Hasday JD, Cohn J, Bleecker ER. Inhibition of exercise-induced bronchospasm by zileuton: a 5-lipoxygenase inhibitor. Am J Respir Crit Care Med 1996; 153: 931-935.

14. Barnes PJ, Brown MJ. Venous plasma histamine in exercise and hyperventilation-induced asthma in man. Clin Sci 1981; 61: 159-162.

15. Lee TH, Brown MJ, Nagy L, Causon R, Walport MJ, Kay AB. Exercise-induced release of histamine and neutrophil chemotactic factor in atopic asthmatics. J Allergy Clin Immunol 1982; 70: 73-81.

16. Deal EC Jr, Wasserman SI, Soter NA, Ingram RH Jr, McFadden ER Jr. Evaluation of role played by mediators of immediate hypersensitivity in exercise-induced asthma. J Clin Invest 1980; 65: 659-665.

17. Hartley JP, Charles TJ, Monie RD, et al. Arterial plasma histamine after exercise in normal individuals and in patients with exercise-induced asthma. Clin Sci 1981; 61: 151-157.

18. Ind PW, Barnes PJ, Brown MJ, Causon R, Dollery CT. Measurement of plasma histamine in asthma. Clin Allergy 1983; 16: 61-67.

19. Ind PW, Brown MJ, Lhoste FJM, Macquin IM, Dollery CT. Concentration effect relationships of infused histamine in normal volunteers. Agents Actions 1982; 12: 12 16.

20. Howarth PH, Pao GJK, Church MK, Holgate ST. Exercise- and isocapnic hyperventilation-induced bronchoconstriction in asthma, relevance of circulating basophils to measurements of plasma histamine. J Allergy Clin Immunol 1984; 73: 391-399.

21. Togias AG, Naclerio RM, Proud D, et al. Nasal challenge with cold, dry air results in release of inflammatory mediators, possible mast involvement. J Clin Invest 1985; 76 : 1375-1381.

22. Jarjour NN, Calhoun WJ, Stevens CA, Salisbury SM. Exercise-induced asthma is not associated with mast cell activation or airway inflammation. J Allergy Clin Immunol 1992; 89: 60-68.

23. Broide DH, Eisman S, Ramdell JW, Ferguson P, Schwartz LB, Wasserman S. Airway levels of mast cell derived mediators in exercise induced asthma. Am Rev Respir Dis 1990; 141: 563-568.

24. Liston TE, Roberts LJ II. Transformation of prostaglandin $\mathrm{D}_{2}$ to 9 alpha, 11 beta-(15S)-trihydroxyprosta-(5Z, 13E)-dien-l-oic acid (9 alpha, 11 beta-prostaglandin F2): a unique biologically active prostaglandin produced enzymatically in vivo in humans. Proc Natl Acad Sci USA 1985; 82: 6030-6034.

25. Holgate ST, Burns GB, Robinson C, Church MK. Anaphylatic and calcium-dependent generation of prostaglandin $\mathrm{D}_{2}\left(\mathrm{PGD}_{2}\right)$, thromboxane $\mathrm{B}_{2}$, and other cyclooxygenase 
products of arachidonic acid by dispersed human lung cells and relationship to histamine release. J Immunol 1984; 133: 2138-2144.

26. MacDermot J, Kelsey CR, Waddell KA, et al. Synthesis of leukotriene $\mathrm{B}_{4}$, and prostanoids by human alveolar macrophages: analysis by gas chromatography/mass spectrometry. Prostaglandins 1984; 27: 163-179.

27. Olez O, Oelz R, Knapp HR, Sweetman BJ, Oates JA. Biosynthesis of prostaglandin $\mathrm{D}_{2}$. Formation of prostaglandin $\mathrm{D}_{2}$ by human platelets. Prostaglandins 1977; 13: 225-234.

28. Granerus G, Bergmark J, Löwhagen O, Thiringer G. Metabolism of ${ }^{14} \mathrm{C}$-histamine given intrabronchially to asthmatic patients. Allergy 1980; 35: 31-36.

29. Kikawa Y, Miyanomae T, Inoue Y, et al. Urinary leukotriene $\mathrm{E}_{4}$ after exercise challenge in children with asthma. J Allergy Clin Immunol 1992; 89: 1111-1119.

30. Smith CM, Christie PE, Hawksworth RJ, Thien F, Lee $\mathrm{TH}$. Urinary leukotriene $\mathrm{E}_{4}$ levels after allergen and exercise challenge in bronchial asthma. Am Rev Respir Dis 1991; 144: 1411-1413.

31. Taylor IK, Wellings R, Taylor GW, Fuller RW. Urinary leukotriene $\mathrm{E}_{4}$ excretion in exercise-induced asthma. $J$ Appl Physiol 1992; 73: 743-748.

32. MacGlashan DWJ, Schleimer RP, Peters SP, et al. Generation of leukotrienes by purified lung mast cells. J Clin Invest 1982; 70: 747-751.

33. Huber M, Kästner S, Schölmerich J, Gerok W, Keppler D. Analysis of cysteinyl-leukotrienes in human urine: enhanced excretion in patients with liver cirrhosis and hepatorenal syndrome. Eur J Clin Invest 1989; 19: 53-60.

34. Roquet A, Dahlen B, Kumlin M, et al. Combined antagonism of leukotrienes and histamine produces predominant inhibition of allergen-induced early and late phase airway obstruction in asthmatics. Am J Respir Crit Care Med 1997; 155: 1856-1863.

35. O'Sullivan S, Dahlén B, Dahlén S-E, Kumlim M. Increased urinary excretion of the prostaglandin $\mathrm{D}_{2}$ metabolite $9 \alpha, 11 \beta$-prostaglandin $\mathrm{F}_{2}$ after aspirin challenge supports mast cell activation in aspirin-induced obstruction. $J$ Allergy Clin Immunol 1996; 98: 421-432.

36. Kumlin M, Stensvad F, Larsson L, Dahlén B, Dahlén S-E.
Validation and application of a new simple strategy for measurements of urinary leukotriene $\mathrm{E}_{4}$ in humans. Clin Exp Allergy 1995; 25: 467-479.

37. Nagakura T, Obata T, Shichijo K, et al. GC/MS analysis of urinary excretion of $9 \alpha, 11 \beta-\mathrm{PGF}_{2}$ in acute and exercise-induced asthma in children. Clin Exp Allergy 1998; 28: 181-186.

38. Crimi E, Balbo A, Milanese M, Miadonna A, Rossi G, Brusasco. Airway inflammation and occurrence of delayed bronchoconstriction in exercise-induced asthma. Am Rev Respir Dis 1992; 146: 507-512.

39. Morgan DJR, Moodley I, Phillips MT, Davies RJ. Plasma histamine in asthmatic and control subjects following exercise: influence of circulating basophils and different assay techniques. Thorax 1983; 38: 771-777.

40. Nagakura T, Lee TH, Assoufi BK, Denison DM, Newman-Taylor AJ, Kay AB. Neutrophil chemotactic factor in exercise- and hyperventilation-induced asthma. Am Rev Respir Dis 1983; 128: 294-296.

41. Lee TH, Brown MJ, Nagy L, Nakagura T, Walport MT, Kay AB. Identification and partial characterisation of an exercise-induced neutrophil chemotactic factor in bronchial asthma. J Clin Invest 1982; 69: 889-899.

42. Zimmermann A, Urbanek R, Kühr J, Stephan V. Harnausscheidung des N-Methylhistamins. Monatsschr Kinderheilkd 1992; 140: 51-56.

43. Granerus G, Simonsson BG, Skoogh B-E, Wetterqvist H. Exercise-induced bronchoconstriction and histamine release. Scand J Respir Dis 1971; 52: 131-136.

44. O'Sullivan S, Roquet A, Dahlén B, Dahlén S-E, Kumlin M. Urinary excretion of inflammatory mediators during allergen-induced early and late phase asthmatic reactions. Clin Exp Allergy 1998, in press.

45. Verhagen J, Bel EH, Kijne GM, et al. The excretion of leukotriene $\mathrm{E}_{4}$ into urine following inhalation of leukotriene $\mathrm{D}_{4}$ by human individuals. Biochem Biophys Res Commun 1987; 148: 864-868.

46. Reiss TF, Hill JB, Harman E, et al. Increased urinary excretion of $\mathrm{LTE}_{4}$ after exercise and attenuation of exercise-induced bronchospasm by montelukast, a cysteinyl leukotriene receptor antagonist. Thorax 1997; 52: 10301035. 